\title{
Portraying child characters in gender perspective: Evaluation of parents awareness about gender stereotypes in Turkish television advertisements ${ }^{1}$
}

\author{
Derya Gül Ünlü² \\ Istanbul University, Faculty of Communication, Turkey
}

doi:10.5937/comman13-15721

\begin{abstract}
As individual becomes a part of social life, helshe starts to learn and interiorize gender roles determined by social structure. Like all social structures, this gender distinction can also be found in media content, because media products are both produced by individuals, who have cultural codes, and also reflect the values of the target audience addressed in order to attract attention. When media products are analysed as the reflectors of gender relations, it can be suggested that child roles used in television advertisements are dependent of these relations. Seeing advertisements between or during the programs helshe watches on television, the child perceives boys and girls as symbolic models. Therefore, investigating the awareness of parents about the contents of television advertisements their children watch, and children's tendencies to take the contents in television advertisements as models is considered important. For this reason, the study aims to investigate parents' opinions about taking these roles as models and their awareness about the connection between these roles and gender relations through child roles presented in television advertisements. Face-to-face interviews were conducted with 20 parents of male and female children between the ages of 7-14. As a result of the research, it was determined that parents do not consider child representations in advertisements realistic, they are aware of the gender-based distinctions between child characters in advertisements, and they are of the opinion that television advertisements have short term effects on children.
\end{abstract}

Key words: gender, parent, child, advertising, television

\footnotetext{
1 This research paper was presented under the title "Evaluation of Parents Awareness Towards the Gender Roles of Child Characters in Turkish Television Advertisements" in the international academic conference "6th International Conference on Studies in Humanities and Social Sciences” held in London on June 27-30th, 2017.

2 Contact with author: derya.gul@istanbul.edu.tr.
} 


\section{Introduction}

As individual becomes a part of social life, he/she starts to learn and interiorize gender roles. Like all social structures, this gender distinction can also be found in media content. When media products are analysed as a reflector of gender relations, it can be suggested that child roles featured in television advertisements are also constructed according to gender roles.

Among the studies which address the effects of gender roles within the context of television content it is observed that several researches focus on advertisements rather than television programs. Television commercial messages represent a significant part of television's total output and very often use subtle production techniques designed to quickly grab the audience's attention and impart pointed and persuasive messages to viewers which make direct connections with core audience needs and lifestyle preference (Furnham et al., 1997: 97). Also, as McArthur and Resko (1975: 210) suggested before, in television advertisements, not only products, but also female, male and child characters, who promote them, are presented. When these characteristics of television advertisements are evaluated, analysing the ways of using characters featured in advertisements becomes inevitable.

Several studies reveal the fact that characters in television advertisements act in accordance with gender roles, and that there is gender-based inequality between these characters. For instance, researches conducted in various countries such as United States (McArthur \& Resko, 1975), United Kingdom (Manstead \& McCulloch, 1981; Harris \& Stobart, 1986; Livingstone \& Green, 1986; Furnham \& Bitar, 1993; Furnham \& Skae, 1997), Italy (Furnham \& Voli, 1989), Portugal (Neto \& Pinto, 1998), Spain (Vallz-Fernandez \& MartinezVicente, 2007); Bulgaria (Ibroscheva, 2007), Australia (Mazzella et al., 1992) and Turkey (Uray \& Burnaz, 2003) determined a gender-based differentiation in television advertisements. "Overall, the studies seem to suggest an unequal representation of the sexes in television advertisements is the norm, not the exception" (Furnham et al., 1997: 92).

These gender roles, which are portrayed based on characters in television advertisements, are also important for the child featured in these advertisements. This is because seeing advertisements between or during the programs he/she watches on television, the child perceives boys and girls in these advertisements as symbolic models. Parents can also be determinants in influencing children about the time to watch television and channels they can watch. Therefore, 
investigating the awareness of parents about the contents of television advertisements their children watch, and children's tendencies to take the contents in television advertisements as models, is considered necessary.

In Turkey, there are various researches conducted on parents' awareness towards television advertisements' effects on children. For instance, Yetim \& Sarıçam (2006: 341) investigated the parents' level of awareness about the effect of cartoons on children. In the study, it was determined that parents are of the opinion that children are affected by cartoons negatively rather than positively, but they allow their children to choose any cartoon they want to watch since they are not well informed about the content. Karaca et al. (2007: 233) suggested that parents think that advertisements harm children and that they are problematic ethically.

On the other hand, as distinct from previous studies, this research aims to present highly educated parents' awareness about gender identity of child roles and effect of these roles on their children. In this context, how gender roles of children in television are constructed will be addressed and possible effects of television advertisements on children will be explained. After this, findings obtained as a result of the interviews conducted with parents will be presented.

\section{Gender of child roles in television advertisements}

Gender differences portrayed in television programs intended for children were addressed by several researchers (Sternglanz \& Serbin, 1974; Frueh \& McGhee, 1975; Miller \& Reeves, 1976; Jennings-Walstedt et al., 1980; McGhee \& Frueh, 1980; Smith, 1994; Thompson \& Zerbinos, 1995; Furnham et al., 1997; Browne, 1998; Uluyağc1 \& Yılmaz, 2007) and it was determined that there is a gender inequality in the contents of different programs intended for children.

Presentation of gender roles is among the main factors which affect children's process of forming an opinion about gender. In this context, television is considered to be a major vehicle through which children learn about appropriate behaviours, particularly gender-appropriate behaviours, and about the relative desirability of performing those behaviours (Neto \& Pinto, 1998: 153154). Advertisements, which are frequently used in mass media, convey many behavioural codes related to gender to the target audience. Therefore, all kind of information presented in advertisements intended for children, shape their way of thinking (Gündüz-Kalan, 2010: 76). 
Laying emphasis on the correlation between television viewing time and acting in accordance with gender role, Courtney and Whipple (1983: 45-46), argue that television advertisements "can influence intellectual development, change attitudes, contribute to aggressive behaviour in children, teach children how to become consumers, encourage prosocial attitudes and behaviours, be an agent of political socialization, and teach racial stereotypes." In this respect, it can be suggested that television advertisements play a significant role in conveying all social roles and norms.

Children obtain information from the advertisements they see or hear through mass media, about how male and female individuals act differently, what men and women must like or how they must act as distinct from each other. On the other hand, the way characters seen in television are generally presented as handsome, easily encourages children to imitate them or take them as models. Advertisements are effective in learning social role of gender in that they are particularly intended for children and therefore reflect their adult gender roles. For this reason, advertisements function as a medium, which helps the reproduction of gender roles as a significant source for children to imitate adult individuals (Uluyağcı \& Yılmaz, 2007: 148).

While a boy character featured in television advertisements is associated with a father, who earns money, chases work, struggles in public life, fights in the army and brings home the bread, girls are portrayed as children playing with dolls and associated with the mother motive, who takes care of housework, raises the children, takes interest in her physical beauty and care, and maintains the continuity of the house (Engin, 2013: 227). Also, in these advertisements, even if children sometimes 'misbehave' by acting against the codes of their gender roles, this can be corrected through the warnings of their mothers and fathers. In this context, Browne (1998: 87) argues that girls are never portrayed as playing with a toy 'suitable' for boys (for instance guns or lorries), while boys are never shown while playing a toy 'suitable' for girls (such as dolls). Smith (1994: 323), on the other hand, lays emphasis on the fact that boys are portrayed outside the house more than girls. In terms of the roles they assume, it can be suggested that girls and boys act in accordance with their gender, and boys act more actively, while girls act more passively (O'Kelly, 1974; Verna, 1975; Welch et al., 1979; Courtney \& Whipple, 1983; Macklin \& Kolbe, 1984). 
It must also be emphasized that, in the advertisements which feature children, in addition to the differences between the roles of boys and girls, there are differences in the formal aspects of advertisements. For example, gender-typing in children's advertisements has also been observed to occur at a structural level with male-oriented advertisements containing more cuts, loud music and boisterous activity, whereas female-oriented advertisements contained more fades and dissolves, soft music and quiet play (Welch et al., 1979: 204).

On the other hand, Fine (2011:231) suggests that children's media restricts children with gender roles, and it is even stricter than the real world during this process. Intensive presentation of gender roles through children's media brought about criticisms about transformation of both children featured in advertisements, and those who watch them, into adults at early ages. For instance, Postman argues that the children we know of also changed due to mass media, and explains his criticism about early transformation of children into adulthood as follows:

"In United States, twelve and thirteen year old girls are among the most highly paid models. In the advertisements published/ broadcast in all visual media, these girls are presented to the public in quite an erotic manner, and in the clothes of smarty and sexually attractive adults." (Postman, 1995: 13)

However, it would be wrong to consider children as individuals who accept all the messages of television advertisements passively, because children are not sponges, who absorb everything conveyed to them. They also make decisions, interpret, accept and reject things. However, children are always exposed to various media content through heroes/heroines, monsters, puppets, good guys/ bad guys and various roles given to male and female characters. For this reason, the child acquires several phenomena consciously or unconsciously, and learns them even if he/she does not want to (Tokgöz, 1979: 97-98).

On the other hand, although children do not accept the advertisement directly, it does not necessarily mean that children are capable of interpreting advertisements with a critical point of view. Therefore, it would not be wrong to suggest that influence of advertisements for children becomes more important when considered from this point of view. Not all advertisements influence children target audience at the same level, only the advertising message which is designed according to target audience becomes successful. Especially advertisements which are fictionalized based on a super hero, cartoon or game charac- 
ters, which children can easily associate themselves with, can be quite successful in terms of directing children (Engin, 2013: 228). However, it is not possible to argue that these characters are independent of gender roles. For instance, in the study conducted by Thompson and Zerbinos (1995: 651) and based on the cartoon characters, it was observed that male individuals are represented more frequently in cartoons which contain adventure, while female individuals are featured in highly stereotyped behaviours in didactic cartoons.

\section{Evaluating the effect of television advertisements on children}

Various researches conducted show that children are aware of roles and behaviours deemed suitable for different genders from their early ages. This awareness develops with the interiorization of gender determinedness and development of the capability to perceive cultural beliefs and norms (Marcus \& Overton, 1978; Martin \& Halverson, 1981; Stangor \& Ruble, 1987). On the other hand, it can be suggested that children can make inferences about the behavioural patterns of not only individuals who they directly interact with, but also about characters they see in various media contents. For instance, in the research conducted by Mayes \& Valentine (1979: 41) on the characters featured in cartoons, it was determined that children between the ages of 8-13 describe characters whose gender is not specifically known and who act more aggressively and dominantly as male, and characters with the opposite features, as female.

Children generally start to understand social norms and behavioural patterns of the culture, in which they live, when they are around 7 years old, and become aware of the differences in gender roles. After 8 years old, the child understands the complicated nature of sex, but can perceive the physiological details after 11. The child forms these first impressions under the influence of his/her own family. Observing the role division between mother and father and how they behave to each other, the child develops an idea about gender (Gündüz-Kalan, 2010: 80).

Awareness of the child, who starts to learn social values and norms at an early age, about the gender roles also develops during this period. It would not be wrong to argue that television advertisements also serve as a reinforcer in this socialization process. According to Bandura (2002: 126), media provide sym- 
bolic models for both children and adults. A significant amount of information about individuals' values, ways of thinking and behavioural patterns, is learned by taking the content in the symbolic environment of media as a model. In this context, there are several models that can be observed in the process of learning gender roles in television (Ruble et al., 1981; Peirce, 1989; Browne, 1998).

The most important aspect of gender roles presented in television advertisements for children is the fact that these roles are learned by 'taking them as models' through 'identification' or 'imitation.' The child identifies himself/herself with male and female roles featured in the media or takes them as models through imitation. For instance, in a study Ruble et al. (1981: 667) conducted on children between the ages of 4-6, it was observed that children take the toys, which the children of the same gender in television play with, as model, and prefer toys, which are suitable for their gender. Therefore, stereotypes in advertising on children's television programs have been a special problem because of their potential impact on gender socialization and, subsequently, children's view of themselves and other people (Browne, 1998: 83).

According to Tokgöz (1979: 104), in majority of studies which investigate influence of television advertisements on children, it is stated that advertisements have two main effects on children:

- Through advertisements, children acquire basic categories which form the process of understanding social experiences.

- Advertisements direct the behaviours of children by including various examples from social structure into their context.

As mentioned above, television advertisements influence children by both providing them the basic categories through which they understand values of the social structure, and teaching them behavioural patterns, which helps them to adopt to the social structure. Considered from this perspective, it would not be wrong to suggest that, with the gender roles featured in television advertisements, children learn both how to evaluate gender roles, and how they can behave in accordance with these roles. Addressed in this context, as Zinkhan (1994: 2) emphasizes, it must be underlined that the most important ethical problem related to television advertisements is the fact that gender role stereotypes portrayed in advertisements are ignored, and it is essential to carry out studies in this field. 


\section{Aim and methodology}

Within the scope of the study, we aim to investigate parents' opinions about taking gender roles as models of children's behaviour and their awareness about the connection between these roles and gender relations presented through child roles in television advertisements. For this purpose, answers were sought to the following questions:

- RQ1: Do parents think that child roles in television advertisement represent their children?

- RQ2: Do parents think that girls and boys in the television advertisements they watched assume different behaviours according to their gender? How do these roles become different from each other?

- RQ3: In parents' opinion, what kind of effect this distinction between girls and boys in advertisements, creates or may create on their child?

Semi-structured interview technique was used in the study in order to find answers to the research questions. During the interviews, three different advertisements, which are broadcasted on Turkish televisions were shown to participants. Advertisements that are intended for children, and explicitly reflect gender roles through children shown to participants are as follows: Haribo candy advertisement, Evy Baby diaper advertisement, Çilek children's room advertisement. After this, various questions were addressed to participants based on the advertisements they watched, in order to answer research questions.

Participants, who have sons and/or daughters between the ages of 7-14, were reached by using quota sampling method. Each interview conducted within the scope of the research lasted 20-30 minutes. Also, since the study was centred on parents' evaluation of gender roles in television advertisements with a critical perspective, participants, with whom interviews were conducted, were included to the study provided that they have a high education background (university, master's degree or doctorate graduates). In addition to this, participants were selected in a manner that they represent different occupational groups so that the study can provide different perspectives.

After interviews were completed, answers to the questions addressed were categorised and analysed. Also, two assistant professors, who are specialized on the subject, were always consulted during data collection stage, data analyses 
were checked and compared with literature and similar research analyses in order to achieve internal validity for the study. For the purpose of achieving external validity, direct quotations were made from the statements of participants while research report was prepared. We also recorded the data obtained from participants, common interview protocol was implemented during the interviews, data were classified under common titles and results were collected in order to achieve internal reliability for the study. For the purpose of achieving external validity, an assistant professor, who is specialized on the subject, reviewed the data and interpretations made as a result of the analyses.

\section{Findings}

Within the scope of the study, semi-structured face-to-face interviews were conducted with twenty participants in total, sixteen female and four male. One participant is between the ages of 30-35, three participants are between the ages of 36-40, nine participants are between the ages of 41-45, and five participants are between the ages of 46-50. One of the participants is single, while nineteen are married. As far as educational background is considered, seventeen participants are graduates of bachelor's degree, and three of them hold of postgraduate degree. Vocational distribution of participants is as follows: eight housewives, two managers at private companies, three specialists at private companies, one veterinary, one doctor, two company owners, two engineers and one teacher.

It is observed that the majority of participants in the study are housewives. In this context, the gender role expectations for the housewives in Turkey are considered worthy to be mentioned. Within the framework of the role of 'housewife', women are assumed to be responsibility for all domestic affairs (such as cleaning the house, cooking food, shopping for the house) and take primary care of their children. Therefore, women who were housewives in the study were treated as if they were working full-time, just like other female participants.

Findings, which were obtained based on participants' opinions about the content of television advertisements intended for children, and effects of these advertisements on children are given below. 


\subsection{Parents' opinions about the representation of child characters in television advertisements}

In the first research question, participants' opinions about 'to what extent girls and boys in television advertisements represent the children in real life' were asked. According to this, the number of parents who are of the opinion that children in advertisements represent the children in real life, was six. On the other hand, fourteen parents stated that children in both advertisements they watched within the scope of the study, and advertisements they remember do not represent the children they see in real life.

According to twelve participants, who think that television advertisements do not represent children in real life, this is so because child characters featured in advertisements come from a high socio-economic background, and these characters do not reflect the educational and income level of Turkey realistically. Two participants stated that it is very obvious that children repeat the lines they memorized, and this causes child characters to be portrayed as characters far from reality. Some of the statements of parents, who think that representation of children in advertisements is problematic, are given below:

I don't think that they represent. It's always the children of highly educated, urban families in advertisements. This does not reflect the income, education level of Turkey, and Turkish family structure. (S.B., 44, Company owner)

Children of educated, white collar mothers and fathers are featured. We see children, who are living in expensive houses and driving luxurious cars. (H.M., 45, Specialist at a private company)

Always certain children types are used in advertisements. That's why they do not seem realistic to me. (...) And also, they all have modern and elegant rooms, houses. Such families reflect a certain section of Turkey. (Y.B., 47, Veterinary)

It is very obvious that children in advertisements repeat memorized lines, and their behaviour is based on their roles; that's why it is not possible for them to represent children in real life. (M.Y., 48, Housewife) 


\subsection{Parents' opinions about the gender roles of male and female children in television advertisements}

Within the scope of the second research question, based on the advertisements they watched, questions related to whether there are any differences in the roles of girls and boys in the advertisements, or whether various behaviour of children (the games they play, their communication with family members and interaction with their friends) vary according to their gender, were addressed to parents. Also, the question whether they observe any such difference not only in the advertisements they watched within the scope of the study, but other advertisements they watched, was asked to the parents.

Seventeen of participants stated that they observed a difference in the roles assumed by child characters according to their gender. According to participants who think that there is a differentiation based on gender roles, boys are generally featured in car advertisements or portrayed while they are playing football with their friends in the garden ot in their house. On the other hand, girls are portrayed while playing with their dolls or household goods, and they act more calmly and maturely. Some of the statements from participants about their observations related to gender-based differences are given below:

In advertisements, the girl is generally playing with dolls, while boys are playing with cars or ball. In my opinion, boys are mostly equipped with violence. (M.Y., 50 , Manager at a private company)

Boys are always shown while playing ball, jumping around, that is, in a mischievous mood. Girls are making cage, or bringing ice-cream to other members of the household in a calmer manner. We can say that girls are more clearheaded. (F.A., 37, Housewife)

In addition to this, participants drew attention to the fact that content of advertisements may also be different according to the gender of children. Some of the statements by participants are given below:

For example, in milk advertisements, boys are playing more actively. Because the possibility of becoming professional basketball players is higher for them. On the other hand, in the advertisements which feature girls, the girl grows up and becomes a mother, and gives the same milk to her daughter. The difference is quite obvious. (H.Ü, 41, Specialist at a private company) 
Boys generally misbehave and dirty up their clothes; for example, in detergent advertisements, children with stained clothes come home. Yes, that's why they act differently according to their gender. (S.İ., 39, Housewife)

Participants also stated that relationship of children with their parents in the advertisements is different according to their gender. Five participants stated that girls are portrayed as imitating their mother, while boys are portrayed as imitating their father. On the other hand, four participants stated that girls are portrayed as spending more time with their father, and boys are portrayed as spending more time with their mother. Some of the statements by participants about the differences in child characters' communication with family members according to their gender, are given below:

I think that boys seem to be spending more time with their father. For instance, in this advertisement [at this point, participant refers to the Cilek room advertisement he is watching], the boy shows his father how to drive, girls are generally not portrayed as individuals who are interested in cars. (...) Girls imitate their mother for instance, in Evy Baby advertisement, girls are dressed like their mother and going shopping. (H.M., 45, Expert at a private company)

I think that, in advertisements, boys are portrayed as spending more time with mother, while girls are portrayed as spending more time with their father. For instance, the girl and her father make a cake together. The boy and his mother play football. (G.K., 41, Housewife)

\subsection{Parents' opinions about the effect of child roles in television advertisements on their own children}

In the last chapter of the research, questions were addressed to participants about whether television advertisements have an influence on their children, if so, what kind of influences there are. Seven participants stated that, they are of the opinion that neither advertisements they watched within the scope of the study, nor other advertisements their children watch, influence their children. According to these advertisements, children do not pay a significant attention to television advertisements. According to one participant, television advertisements attract the attention of children at early ages for a short span of time since they are very colourful and loud. 
On the other hand, thirteen participants in the research stated their observation that television advertisements have an influence on both their children and other children around them. However, while nine of the participants stated that this effect is not very significant and is forgotten by children in a short time, four participants stated that children do not forget advertisement slogans or lines in the advertisements. Some of the statements by participants, who think that advertisements have an effect on children, are as follows:

Generally, they may imitate some behaviour which attract their attention in the advertisement. But this doesn't last long. After a while, they forget to act like that. (T.K., 35, Housewife)

I think it doesn't affect their behaviour directly. But they may keep on saying advertisement's slogan or a line. I think that this is the most important aspect that affects children... (F.G., 41, Housewife)

Three participants who are of the opinion that television advertisements are influential, also stated that other media products such as films and series stand out more in terms of influencing children. In this context, some of the statements by participants about their opinion on the effects of television advertisements on children are given below:

I don't think that children are very into advertisements. There are other programs such as cartoons, television series, which affect them more. They are influenced by the characters in these programs more. Advertisements play a secondary role compared to other programs. (F.K., 43, Housewife)

Television advertisements may also be influential, but I think that children do not remember them well since they keep changing. (...) I believe that cartoons are more effective. The child watches a cartoon until helshe grows up. For instance, Pepe or Dora the Explorer, all kind of products are released to the market with these products as brands. From bags to bed spreads. The child forgets the products helshe sees in the advertisement but does his/her best to convince the parent to buy goods which feature these characters. (F.A., 37, Housewife) 


\section{Conclusion}

With the process of socialization, the individual starts to learn gender roles determined by social structure and interiorize those which are suitable for his/ her gender. This gender-based difference is also reflected in media content. In this respect, advertisements, which are among important media products, also reflect this differentiation between genders with both content and form.

As Bandura (2002: 126) argues, when analysed as symbolic models, it would not be wrong to suggest that advertisements provide infinite number of characters, which can serve as models for the target audience. Therefore, investigating the awareness of parents about the contents of television advertisements their children watch, and children's tendencies to take the contents in television advertisements as models was aimed within the scope of the research. For this reason, parents' opinions about taking these roles as models and their awareness about the connection between these roles and gender relations through child roles presented in television advertisements were investigated in the study.

According to research results, parents stated that child characters featured in television advertisements do not represent children in real life. According to the parents who participated in the research, child characters featured in television advertisements have a high socio-economic background, and therefore do not reflect the educational and economic level of Turkey realistically. In addition to this, parents stated that behavioural patterns and roles of children in television advertisements are different according to their gender. According to participants, while boys are portrayed as behaving more actively outside the house, girls are portrayed as spending more time at home and performing more passive activities. Also, according to parents, the content of the advertisement may also be determinant for the gender of child character featured in that advertisement, and the family member, with whom the child establishes intimate relationship (mother and father) differs according to child character's gender. In addition to this, parents stated that they think that children are influenced by the advertisements they watch, but they are not of the opinion that this influence is at high levels. According to them, the aspects of advertisements which affect children most are catchy slogans and lines. However, this effect continues for quite a short period of time and it is forgotten by children after a while.

Therefore, it can be suggested that parents do not find child representation in advertisements realistic, child characters in advertisements are portrayed dif- 
ferently according to their gender, and they have a certain level of awareness about this. In addition to this, it was determined that parents are not aware of television advertisements' effect on their children, and they are even of the opinion that there is no such effect. There are a number of studies (Calvert \& Aletha, 1987; Luecke-Aleksa et al., 1995; Signorielli, 1990; Signorielli, 2001) highlighting that gender roles in television commercials have an impact on how children perceive gender differences and learn to discriminate on gender roles. However, in the interviews conducted, it has been one of the important findings of research that parents have expressed that TV commercials do not have much effect on their children. In the next studies to be carried out, it is important to focus not only the commercials, but also the effect of different media texts on children and perceptions held by parents. 


\section{References}

Bandura, A. (2002). Social Cognitive Theory of Mass Communication. In J. Bryant \& D. Zillmann (eds.), Media Effects: Advances in Theory and Research (pp. 94-124). New Jersey: Lawrence Erlbaum Associates.

Browne, B. A. (1998). Gender Stereotypes in Advertising on Children's Television in the 1990s: A Cross-National Analysis. Journal of Advertising, 27(1): 83-96.

Calvert, S. L. \& Aletha, C. H. (1987). Television and Children's Gender Schemata. New Directions for Child and Adolescent Development, 38: 75-88.

Courtney, A. E. \& Whipple T.W. (1983). Sex Stereotyping in Advertising. Lexington: MA: D.C. Heath.

Engin, H. B. (2013). Çocuk ve Reklam: Çocuklar Olması Gerekenden Erken Büyüyor. I. Türkiye Medya ve Çocuk Kongresi Bildiriler Kitabı, 217-233.

Fine, C. (2011). Toplumsal Cinsiyet Yanılsaması. İstanbul: Sel Yayıncılık.

Frueh, T. \& McGhee, P. E. (1975). Traditional Sex Role Development and Amount of Time Spent Watching Television. Developmental Psychology, 11(1): 109-114.

Furnham, A., Abramsky, S. \& Gunter, B. (1997). A Cross-Cultural Content Analysis of Children's Television Advertisements. Sex Roles, 37(1): 91-99.

Furnham, A. \& Bitar, N. (1993). The Stereotyped Portrayal of Men and Women in British Television Advertisements. Sex Roles, 29(3-4): 297-310.

Furnham, A. \& Skae, E. (1997). Changes in the Stereotypical Portrayal of Men and Women in British Television Advertisements. European Psychologist, 2(1): 44-51.

Furnham, A. \& Voli, V. (1989). Gender Stereotypes in Italian Television Advertisements. Journal of Broadcasting \& Electronic Media, 33(2): 175-185.

Gündüz-Kalan, Ö. (2010). Reklamda Çocuğun Toplumsal Cinsiyet Teorisi Bağlamında Konumlandırılışı: 'Kinder' Reklam Filmleri Üzerine Bir İnceleme. Istanbul University Faculty of Communication Journal, 38(1): 75-89. 
Harris, P. R. \& Stobart, J. (1986). Sex Role Stereotyping in British Television Advertisements at Different Times of the Day: An Extension and Refinement of Manstead \& McCulloch (1981). British Journal of Social Psychology, 25(2): 155-164.

Ibroscheva, E. (2007). Caught Between East and West? Portrayals of Gender in Bulgarian Television Advertisements. Sex Roles, 57(5-6): 409-418.

Jennings-Walstedt, J., Geis, F. L. \& Brown, V. (1980). Influence of Television Commercials on Women's Self-Confidence and Independent Judgment. Journal of Personality and Social Psychology, 38(2): 203-210.

Karaca, Y., Pekyaman, A. \& Güney, H. (2007). Ebeveynlerin Televizyon Reklam İçeriklerinin Çocuklar Üzerindeki Etkilerini Etik Açıdan Algılamalarına Yönelik Bir Araştırma. Sosyal Bilimler Dergisi, 9(2): 233-249.

Livingstone, S. \& Green, G. (1986). Television Advertisements and the Portrayal of Gender. British Journal of Social Psychology, 25(2): 149-154.

Luecke-Aleksa, D., Anderson, D. R., Collins, P. A. \& Schmitt, K. L. (1995). Gender Constancy and Television Viewing. Developmental Psychology, 31(5), 773-780.

Macklin, M. C. \& Kolbe, R. H. (1984). Sex Role Stereotyping in Children's Advertising: Current and Past Trends. Journal of Advertising, 13(2): 34-42.

Manstead, A. S. \& McCulloch, C. (1981). Sex-Role Stereotyping in British Television Advertisements. British Journal of Social Psychology, 20(3): 171-180.

Marcus, D. E. \& Overton, W. F. (1978). The Development of Cognitive Gender Constancy and Sex Role Preferences. Child Development, 49(2): 434-444.

Martin, C. L. \& Halverson C. F. (1981). A Schematic Processing Model of Sex Typing and Stereotyping in Children. Child Development, 52(4): 1119-1134.

Mayes, S. L. \& Valentine. K. B. (1979). Sex Role Stereotyping in Saturday Morning Cartoon Shows. Journal of Broadcasting \& Electronic Media, 23(1): $41-50$. 
Mazzella, C., Durkin, K., Cerini, E. \& Buralli, P. (1992). Sex Role Stereotyping in Australian Television Advertisements. Sex Roles, 26(7): 243-259.

McArthur, L. Z. \& Resko, B. G. (1975). The Portrayal of Men and Women in American Television Commercials. The Journal of Social Psychology, 97(2): 209-220.

McGhee, P. E. \& Frueh, T. (1980). Television viewing and the Learning of SexRole Stereotypes. Sex Roles, 6(2): 179-188.

Miller, M. M. \& Reeves, B. (1976). Dramatic TV Content and Children's SexRole Stereotypes. Journal of Broadcasting \& Electronic Media, 20(1): 35-50.

Neto, F. \& Pinto, I. (1998). Gender Stereotypes in Portuguese Television Advertisements. Sex Roles, 39(1/2): 153-164.

O'Kelly, C. G. (1974). Sexism in Children's Television. Journalism Quarterly, 51(4): 722-724.

Peirce, K. (1989). Sex Role Stereotyping of Children on Television: A Content Analysis of the Roles and Attributes of Child Characters. Sociological Spectrum, 9(3): 321-328.

Postman, N. (1995). Çocukluğun Yokoluşu. Ankara: İmge Yayınevi.

Ruble, D. N., Balaban, T. \& Cooper, J. (1981). Gender Constancy and the Effects of Sex-Typed Televised Toy Commercials. Child Development, 52: 667-673.

Signorielli, N. (1990). Children, Television, and Gender Roles: Messages and Impact. Journal of Adolescent Health Care, 11(1): 50-58.

Signorielli, N. (2001). Television's Gender Role Images and Contribution to Stereotyping: Past, Present, Future. In. G. D. Singer \& J. L. Singer (eds.), Handbook of Children and the Media. (pp. 341-358). London: Sage Publications.

Smith, L. J. (1994). A Content Analysis of Gender Differences in Children's Advertising. Journal of Broadcasting \& Electronic Media, 38(3): 323-337.

Stangor, C. \& Ruble, D. N. (1987). Development of Gender Role Knowledge and Gender Constancy. New Directions for Child and Adolescent Development, 38: 5-22. 
Sternglanz, S. H. \& Serbin, L. A. (1974). Sex Role Stereotyping in Children's Television Programs. Developmental Psychology, 10(5): 710-715.

Thompson, T. L. \& Zerbinos, E. (1995). Gender Roles in Animated Cartoons: Has The Picture Changed in 20 Years?. Sex Roles, 32(9-10): 651-673.

Tokgöz, O. (1979). Televizyon Reklamları ve Çocuklar. Ankara Üniversitesi Siyasal Bilgiler Fakültesi Dergisi, 34(1-2), 93-110.

Uluyağcı, C. R. \& Yılmaz, A. (2007). Televizyon Reklamlarında Çocuğa İlişkin Toplumsal Cinsiyet Rollerinin Sunumu. Galatasaray Üniversitesi İletişim Dergisi, 6: 141-157.

Uray, N. \& Burnaz, Ş. (2003). An Analysis of the Portrayal of Gender Roles in Turkish Television Advertisements. Sex Roles, 48(1): 77-87.

Valls-Fernández, F. \& Martínez-Vicente, J. M. (2007). Gender Stereotypes in Spanish Television Commercials. Sex Roles, 56(9-10): 691-699.

Verna, M. E. (1975). The Female image in children's TV commercials. Journal of Broadcasting \& Electronic Media, 19(3): 301-309.

Welch, R. L.,Huston-Stein, A., Wright, J. C. \& Plehal, R. (1979). Subtle Sex Role Cues in Children's Commercials. Journal of Communication, 29(3): 202-209.

Yetim, G. \& Sarıçam, H. (2006). Çizgi Film Programlarının Çocuklara Etkisi Konusunda Ailelerin Farkındalık Düzeylerinin İncelenmesi. 11. Ulusal Okul Öncesi Ë̆itimi Öğrenci Kongresi, 341-364.

Zinkhan, G. M. (1994). Advertising Ethics: Emerging Methods and Trends. Journal of Advertising, 23(3): 1-4. 
